\title{
Wykorzystanie Nowej Ekonomii Strukturalnej dla modernizacji i zwiększenia innowacyjności polskiej gospodarki
}

\begin{abstract}
W ostatecznym rozrachunku decydujące znaczenie dla sukcesu modernizacyjnego Polski będzie miało promodernizacyjne nastawienie przedsiębiorców, pracowników i konsumentów (a więc całego społeczeństwa). Aparatura Nowej Ekonomii Strukturalnej może być pomocna we wzmocnieniu roli państwa w sprostaniu wyzwaniom stojącym przed polską gospodarką, trzeba jednak mieć świadomość, że zastosowanie NES może zderzyć się z wieloma istotnymi wyzwaniami i ograniczeniami. Po pierwsze, duże firmy potrzebne do tworzenia innowacyjnej koalicji rozwojowej są albo własnością korporacji zagranicznych, albo pozostają własnością państwa. Po drugie, nieliczne polskie małe i średnie firmy rosną dostatecznie, aby podjąć wysiłek konkurencji globalnej. Po trzecie, społeczeństwo, a w tym i przedsiębiorcy, odnoszą się nieufnie do instytucji państwa, a państwo z dużą nieufnością podchodzi do publiczno-prywatnych przedsięwzięć. I wreszcie, po czwarte, Polacy po latach niedoboru chcą konsumować, a nie oszczędzać, tym samym nie są podatni na obietnice poprawy przyszłego poziomu życia w zamian za zdyscyplinowane służenie interesom państwa i korporacji.
\end{abstract}

Słowa kluczowe: modernizacja, innowacje, rola państwa, przydatność NES.

\section{Wprowadzenie}

W ostatnich dekadach napisano tysiące artykułów i książek o innowacyjności przedsiębiorstw. Teorie Schumpetera z marginesu przesunęły się do głównego nurtu rozważań ekonomicznych. W tym kontekście rola państwa przedstawiana jest jako działalność wspomagająca inicjatywy przedsiębiorców i uczonych w ramach ekonomii wiedzy (knowledge economy).

Nowa Ekonomia Strukturalna (NES) inaczej rozkłada akcenty współzależności między państwem a podmiotami gospodarki - przedsiębiorstwami i gospodarstwami domowymi (czy w nomenklaturze funkcji produkcji: między kapitałem i pracą). W dalszej części staramy się pokazać w jakim zakresie jest to podejście lepiej dostosowane do wyzwań stojących przed gospodarkami usiłują- 
cymi dogonić kraje rozwinięte, w tym gospodarką polską jako małą gospodarką otwartą, a w jakim - podejście to może napotkać inherentne trudności.

Jak pokazywaliśmy w innym miejscu, zalecenia NES nie mogą być dosłownie przeniesione na warunki polskie. Wynika to w pierwszej kolejności z odmiennych długotrwałych uwarunkowań kulturowych - braku analogii dla tradycji relacji społecznych zbudowanych na gruncie konfucjanizmu (Jędrzejczak i Sterniczuk, 2017). Dodatkowym ograniczeniem są zobowiązania Polski w sieci powiązań prawnych i instytucjonalnych Unii Europejskiej - ograniczających dostępność pewnych mechanizmów polityki gospodarczej, np. przez zakaz subsydiowania firm oraz wymóg przestrzegania norm produktowych, ekologicznych oraz warunków pracy.

Nie oznacza to jednak nieprzydatności zasad i doświadczeń NES. Widzimy trzy wymiary jej wykorzystania, przystosowane do konkretnych realiów i wyzwań gospodarczej modernizacji Polski:

1) przeformułowania paradygmatu gospodarki,

2) formułowania i prowadzenia polityki gospodarczej,

3) uczestnictwa w gospodarce światowej.

W dalszej części zajmiemy się bardziej szczegółowo tymi trzema wymiarami możliwego wykorzystania NES w realizacji polskich wyzwań modernizacyjnych.

\section{Przeformułowanie paradygmatu gospodarki}

Pojęcie paradygmatu - założeń myślenia o gospodarce - wydaje się nie mieć wiele wspólnego ze skutecznym wykorzystaniem NES w rozwiązywaniu problemów innowacyjnej modernizacji polskiej gospodarki A.D. 2018. Tak jednak nie jest. Należy zauważyć, że paradygmat gospodarki rynkowej, jaki znamy z teorii ekonomii, jest produktem XIX wieku z domieszką legitymizacji dla działań rządu obserwowanych po wielkim kryzysie lat dwudziestych. To wtedy utrwalały się różne fragmenty rozumienia czym jest gospodarka rynkowa, jakie są jej „czyste” lub właściwe powiązania z państwem i jakie rozwiązania polityki gospodarczej mieszczą się w obrębie tego przyjętego paradygmatu gospodarki.

Środowisko ekonomistów i polityków gospodarczych z wielkim trudem i niechęcią dopuszcza zmianę paradygmatu, w ramach którego operuje. Jest to wynik nie tylko obrony karier, lecz także, a może przede wszystkim, znajomości i powszechności metodologii, a więc języka, w którym grupa się porozumiewa. 
W wielkim skrócie, podstawą (punktem wyjścia) obowiązującego paradygmatu myślenia o gospodarce rynkowej jest system wolnych w swych wyborach jednostek kierujących się zasadą maksymalizacji korzyści (homo oeconomicus). Wolny rynek może prowadzić do rozwiązań suboptymalnych, co jednak jest wynikiem niedoskonałości (market failure), a nie strukturalnych (nienaprawialnych) właściwości rynku. Spór toczy się więc o skalę niedoskonałości alokacji przez rynek. Istniejące spektrum poglądów zaczyna się od stanowiska, iż niewidzialna ręka rynku potrzebuje państwa tylko jako „nocnego stróża” pilnującego zasad fair play między uczestnikami rynku, a kończy się na przypisywaniu państwu ról zarówno pilnowania reguł gry, jak i twórcy oraz administratora infrastruktury gospodarczej i tzw. strategicznych przedsiębiorstw ${ }^{1}$.

W naszym rozumieniu, NES jest odejściem od rozumienia gospodarki jako „rynku, który wymaga większego lub mniejszego wsparcia ze strony państwa” na rzecz paradygmatu przedsiębiorców i państwa jako równorzędnych partnerów w podejmowaniu decyzji gospodarczych ${ }^{2}$. Jest to więc teza znacznie mocniejsza niż, przykładowo, pogląd wynikający z keynesizmu o uzupełniającej fiskalnej i monetarnej roli państwa w przywracaniu równowagi pełnego zatrudnienia.

Nie oznacza to jednak, że w NES partnerstwo między rynkiem a państwem jest zadaniem łatwym i nierodzącym napięć. Są to jednak problemy realizacji, a nie pryncypiów. NES promuje punkt widzenia, że wobec wyzwań, z którymi mierzą się tzw. kraje doganiające zamykanie się w ramach dyskusji „rynek czy państwo" nie prowadzi do dobrych rozwiązań, a raczej marnuje potencjał intelektualny na fałszywe spory, zasoby materialne zaś na tworzenie i wdrażanie nierealistycznych rozwiązań.

Trzeba podkreślić, że jest to perspektywa jakościowo inna od propozycji dominującej roli państwa (np. Mazucatto, 2013), która mimo wszystko jest stanowiskiem w sporze rynek czy państwo.

Paradygmat gospodarki NES, zakładając partnerstwo przedsiębiorców i państwa, wcześniej musiał założyć, że obie strony są do pewnego stopnia sobie

1 Ekstrema: (a) całkowitego wyeliminowania rynku, po latach daremnych prób krajów komunistycznych, znalazło swoje zasłużone miejsce na śmietniku historii, oraz (b) rynku bez państwa znalazło swoje schronienie na stronach Internetu.

2 NES nie poświęca istotnej uwagi gospodarstwom domowym jako podmiotom decyzji gospodarczych (jak to ma miejsce w ekonomii głównego nurtu wywodzącej się z klasycznego paradygmatu). Nie wynika to w naszym przekonaniu z lekceważenia decyzji gospodarstw domowych co do zachowań na rynku pracy oraz poziomu i struktury konsumpcji, ale ze względów pragmatycznych - możliwość kształtowania zachowań gospodarstw domowych wymaga dużo czasu (wręcz generacji), a rezultaty są niepewne. Ponadto NES to propozycja dla krajów doganiających, gdzie „głód pracy i podstawowych dóbr konsumpcyjnych” jest dominujący w decyzjach gospodarstw domowych. 
równe. Oznacza to, paradoksalnie, nie tyle wzmocnienie państwa, ile że państwo jest skłonne do samoograniczenia swoich instrumentów. Jest to koncepcja nawiązująca do historii rozwoju Japonii, później Korei Południowej, a obecnie realizowana jest w Chinach.

Formy partnerstwa można było odszukać w działaniach koalicji rozwojowej rządu i chaebols w Korei Południowej lub rządu i prywatnych korporacji w rozwoju Japonii w latach 1946-1970. W obu przypadkach to partnerstwo przebiegało w kontekście kultury będącej spadkobiercą konfucjanizmu, gdzie liberalna, zachodnia koncepcja partnerstwa jako współpracy równorzędnych aktorów jest wprost niewyobrażalna, szczególnie w tradycyjnych społeczeństwach, jakimi były te kraje. Nie można jednak wpaść w pułapkę stosowania zachodniego myślenia o dominacji państwa opartej na instrumentach administracyjnego przymusu. Zarówno w Japonii, jak i w Korei była to komunikacja pomiędzy władzą państwa a wolnymi, prywatnymi przedsiębiorcami. Przykładowo, utrzymywanie odrębnej opinii czy wręcz niechęć do działań zalecanych przez wszechwładne Ministerstwo Handlu Międzynarodowego i Przemysłu (MITI) w Japonii nie groziło ani utratą stanowiska, ani tym bardziej utratą własności prywatnego przedsiębiorstwa. Podobnie było w Korei Południowej. Zapobiegało to między innymi kumulacji błędów w polityce gospodarczej i wybranych kierunków rozwoju przedsiębiorstw.

Dobrą ilustracją tej zależności jest relacja między rządem i przedsiębiorcami w Japonii lat 50. XX wieku. Otóż MITI było na początku przeciwne rozwojowi przemysłu samochodowego oraz elektroniki. Samochody ciężarowe, maszyny budowlane, elementarny sprzęt gospodarstwa domowego były akceptowane, ale prywatne auta czy wyszukana elektronika - już nie. Biznes uparcie dążył jednak do celu i po latach ta rebeliancka koncepcja została przez MITI zaakceptowana, choć na początku strumień pomocy rządowej omijał te „nieprawomocne” biznesy. Jak wiadomo, efektem tego kierunku rozwoju było uzyskanie przez Japonię i Koreę dominującej pozycji na rynkach światowych.

Partnerstwo pomiędzy państwem a korporacją jest trudne do wyegzekwowania ze względu na różnicę wagi tych dwóch aktorów - państwo może w ostateczności odwołać się do swojego monopolu „użycia przemocy”. Niemniej jednak, gdy państwo ma za partnera prywatną korporację poszanowanie prywatnej własności wyznacza granicę forsowanych koncepcji rozwojowych. W omawianym przypadku, gdyby MITI miało więcej kontroli nie mielibyśmy prawdopodobnie ani Sony, ani japońskich samochodów lub przynajmniej ich tworzenie uległo by poważnemu opóźnieniu. Partnerstwo oznacza zarazem i współpracę, i spór, a w ostateczności możliwość zerwania relacji. Tworzy to zdrową zasadę konieczności analizy perspektywy partnera i uzasadniania swojego stanowiska, zmu- 
sza do kompromisu. Te procesy umożliwiają wzajemną adaptację i tworzenie nowych rozwiązań będących bliżej opcji cenionych przez partnerów.

W tym kontekście niezwykle ciekawe dla gospodarki globalnej jest doświadczenie Chin. Ze względu na historyczną zaszłość skrajnie upaństwowionej gospodarki, mamy obecnie do czynienia z celowym „hodowaniem” przez państwo prywatnych korporacji mogących stać się partnerami programu modernizacyjnego.

Podsumowując, obok państwa jako twórcy polityki gospodarczej i kontrolera jej realizacji poprzez własność i podobnie drastyczne formy oraz państwa jako nocnego stróża jest więc miejsce dla państwa partnera prywatnego biznesu. Ta koncepcja wymaga jednak spełnienia dwóch elementarnych warunków, ze strony państwa - akceptacji faktu partnerstwa $\mathrm{z}$ autonomicznymi podmiotami zdolnymi kalkulować swoje interesy biznesowe, a tym samym poszanowania tych kalkulacji, natomiast ze strony biznesu - przyjęcia współodpowiedzialności za rozwój gospodarki, czyli systemu wykraczającego poza wąskie interesy pojedynczego biznesu. Tak właśnie stało się w Japonii i w Korei Południowej. W obu przypadkach mieliśmy do czynienia z ukształtowaniem się koalicji rozwojowych biznesu i państwa. W obu wypadkach także udało się przekonać resztę społeczeństwa do akceptacji tej koalicji i wysokiego poziomu oszczędności, co pozwalało na wysoką stopę inwestycji.

\section{Formułowanie i prowadzenie polityki gospodarczej}

Celem NES jest „wspomagana konwergencja” - działania na rzecz dogonienia wysoko rozwiniętych, zamożnych krajów Zachodu przez kraje aspirujące do dołączenia do tego ekskluzywnego klubu.

Zarówno teoria, jak i praktyka doganiania nie są zjawiskiem historycznie nowym, czego przykład daje np. Rosenstein-Rodan (1943).

Historycznym przykładem udanej modernizacji zarządzanej przez państwo są Prusy początku XIX wieku, które można uznać za wzór pioniera udanej centralnie zarządzanej całościowej reformy, jak mówi jeden z jej twórców, opartej na „trójwymiarowym prymacie: armii, wiedzy i konstytucji” (Gneisenau, za: Nipperdey, 1998).

Historia gospodarcza pokazuje jednak, że udana konwergencja przez modernizację jest niestety zjawiskiem stosunkowo niezbyt częstym. We współczesnym świecie konwergencja jest trudniejsza niż w historycznej przeszłości - oznacza bowiem nie tyle przyśpieszenie wzrostu przez wykorzystanie nieaktywnych zaso- 
bów pracy ${ }^{3}$, ile modernizację gospodarki przez alokacje czynnych zasobów do działań o wyższej wartości dodanej. W pierwszej kolejności jest to wyzwanie „modernizacji pasywnej” polegającej na adaptacji rozwiązań z Zachodu. W drugiej zaś - jest to wyzwanie „modernizacji aktywnej” opartej na tworzeniu i wdrażaniu oryginalnych własnych rozwiązań innowacyjnych.

Przyczyny sukcesów, ale i porażek programów modernizacyjnych można doszukać się zarówno po stronie struktury procesu modernizacji, jak i praktyki zarządzania tymże procesem ${ }^{4}$.

\subsection{Strukturalne uwarunkowania procesu modernizacji}

Po stronie struktury procesu modernizacji podstawowym problemem jest nieuniknione napięcie między „cyklem politycznym” a „cyklem modernizacyjnym”. O ile cykle polityczne w demokracjach operują w perspektywie kilku lat „od wyborów do wyborów”, o tyle cykle modernizacyjne realizują się w perspektywie kilkunastoletniej wyznaczonej przez znaczące zwiększenie udziału gospodarki opartej na produktach innowacyjnych. Modernizacja systemowa, a więc polegająca na masowych innowacjach (a nie kilku nawet spektakularych udanych innowacjach wprowadzonych ad hoc) wymaga działań w długim okresie, wystarczającym dla przeprowadzenia i ,zakorzenienia” zmian instytucjonalnych i regulacyjnych decydujących o skutecznym transferowaniu wiedzy do gospodarki, jak również internalizacji odpowiednich zachowań uczestników. Stąd zrozumiała jest pokusa wśród krajów doganiających poświęcenia demokracji na rzecz modernizacji. Przypadek Chin również w tym względzie wprowadza historyczny precedens. Jeszcze kilka dekad temu przeważał pogląd, iż demokracja polityczna typu zachodniego jest warunkiem niezbędnym modernizacji, jednakże dotychczasowe sukcesy modernizacyjne Chin co najmniej osłabiają tę tezę. Oczywiście w przypadku Polski, chociażby ze względów zobowiązań międzynarodowych, taki dylemat nie ma miejsca, choć akceptowalny model demokracji, z uwagi na poszczególne rozwiązania realizowanej praktyki, jest dosyć pojemny.

W tym kontekście deklaracje polityków, ale również przedsiębiorców i menedżerów, iż innowacje - szczególnie oparte na rodzimej wiedzy - są warte bezwarunkowego poparcie są podejrzane. Innowacje oznaczają bowiem zaburzenie

3 Choć to też ma znaczenie szczególnie w ludnych Chinach i Indiach, a w perspektywie dekad również w Afryce.

$4 \quad$ Trzeba też jednak pamiętać, że konkretne historyczne przypadki sukcesu czy porażki zależą również od wielu niekontrolowanych czynników, jak np. osobowości przywódcy, przełomowych wydarzeń politycznych czy technologicznych, zagrożeń zewnętrznych. Tymi bez wątpienia ważnymi zjawiskami się nie zajmujemy. 
status quo i to na wielu poziomach. Innowacje powodują większe lub mniejsze zakłócenie porządku gospodarczego i społecznego dla wielu grup społecznych, przynajmniej w krótkim i średnim horyzoncie czasowym.

Z punktu widzenia państwa szczególnie zakłócający wpływ innowacji rozgrywa się na wrażliwym politycznie rynku pracy. Dlatego też zjawisko „zabijania innowacyjności" przez państwową politykę ochrony miejsc pracy w starych sektorach gospodarki jest reakcją uzasadnioną cyklem politycznym. Po pierwsze, związki zawodowe w starych sektorach są dobrze osadzone w strukturach politycznych. Nierzadko także zawody schyłkowych sektorów są postrzegane wysoko w społecznej gradacji zawodów (w Polsce takim przykładem jest zawód górnika). Sektory nowe, innowacyjne są pozbawione takich przewag $-\mathrm{z}$ definicji oferują mało miejsc pracy, a na dodatek często stanowią zagrożenie dla miejsc pracy w starych sektorach gospodarki.

Powodzenie (lub nie) społecznego procesu modernizacji przez innowacje jest uwikłane w cyrkularną zależność o charakterze „błędnego koła” (vicious circle): innowacje są motorem rozwoju, jednak aby innowacje stały się zjawiskiem napędzającym wzrost, potrzebne jest osiągnięcie dostatecznie zaawansowanego poziomu rozwoju gospodarczego. W konsekwencji, wyzwanie modernizacyjne na poziomie strukturalnym to przejście od gospodarki niskiego potencjału innowacyjnego (rys. 1) do gospodarka wysokiego potencjału innowacyjnego (rys. 2).

Rysunek 1. Cykl gospodarki niskiego potencjału innowacyjnego

\begin{tabular}{|c|c|c|}
\hline $\begin{array}{l}\text { Prosta niskoptatna } \\
\text { praca potaczona } \\
\text { z wysokim bezrobociem } \\
\text { i niskim poziomem } \\
\text { aktywności zawodowej }\end{array}$ & $\rightarrow$ & $\begin{array}{l}\text { Niski popyt } \\
\text { wewnętrzny i duża } \\
\text { niepewność pracy, } \\
\text { maty popyt na } \\
\text { produkty i ustugi } \\
\text { o dużej zawartości } \\
\text { wiedzy }\end{array}$ \\
\hline 4 & & $\downarrow$ \\
\hline $\begin{array}{l}\text { Utrwalanie } \\
\text { ekstensywnego modelu } \\
\text { gospodarczego do } \\
\text { czasu wyczerpania } \\
\text { nadwyżek prostej } \\
\text { i taniej pracy }\end{array}$ & & $\begin{array}{l}\text { Brak motywacji dla } \\
\text { innowacji: niskie } \\
\text { wydatki na } B \& R \text {, mate } \\
\text { kapitatowe inwestycje } \\
\text { (maszyny i kadry) }\end{array}$ \\
\hline
\end{tabular}

Rysunek 2. Cykl gospodarki wysokiego potencjału innowacyjnego

$\begin{array}{ll}\begin{array}{l}\text { Preferencje fiskalne dla } \\ \text { ksztatcenia pracowników } \\ \text { i inwestycji } \\ \text { innowacyjnych } \\ \begin{array}{l}\text { Proinnowacyjne } \\ \text { zamówienia publiczne }\end{array}\end{array} & \begin{array}{l}\text { Wzrost ilości dobrze } \\ \text { ptatnych miejsc pracy } \\ \text { daje wzrost popytu na } \\ \text { produkty innowacyjne }\end{array} \\ \qquad & \\ \begin{array}{l}\text { Przesuwanie w stronę } \\ \text { intensywnego modelu } \\ \text { rozwoju z rosnacym } \\ \text { wykorzystaniem wiedzy } \\ \begin{array}{l}\text { i specjalizowanej } \\ \text { pracy }\end{array}\end{array} & \begin{array}{l}\text { Motywacja do } \\ \text { innowacji: zwiększone }\end{array} \\ & \begin{array}{l}\text { wydatki na B\&R, } \\ \text { kapitatowe inwestycje } \\ \text { w firmę } \text { i ksztatcenie } \\ \text { pracowników }\end{array}\end{array}$

Przejście od cyklu niskiego potencjału innowacyjnego do cyklu wysokiego potencjału innowacyjnego wymaga czasu oraz zarówno ekonomicznych, jak 
i społeczno-politycznych zmian. Aby kontynuacja tych wysiłków była możliwa w sposób nieprzerywany cyklem politycznym, konieczny jest concensus elit polityczno-gospodarczych. Przykład rozwoju Korei Południowej pokazuje jak ważne jest takie porozumienie.

Porozumienie elit politycznych i gospodarczych było na początku wymuszone przez dyktaturę generała Parka, jednak później zostało dość powszechnie przyjęte i jest kontynuowane do dzisiaj. W Korei okres przejściowy obejmował sześć 5-letnich planów rozwoju. Do połowy lat 70. XX wieku motorem była tania praca, później do połowy lat 90 . były to inwestycje. Okres budowy potencjału został ukoronowany w 1996 roku członkostwem w OECD, a następnie intensywną koncentracją na innowacjach (U.S. Bureau of Labor Statistics, 2018).

Często, jako warunek przejścia od cyklu niskiego potencjału innowacyjnego do cyklu wysokiego potencjału innowacyjnego przyjmuje się poziom nakładów na badania i rozwój (B\&R). Nakłady te są oczywiście warunkiem koniecznym udanego przejścia jednakże z punktu widzenia polityki modernizacyjnej podstawowe znaczenie ma struktura nakładów (udział państwowych i prywatnych uczestników sektora badawczego) oraz „ssanie” innowacji przez przemysł. Strategia wymuszania innowacyjności przez znaczne zwiększanie wydatków państwa na $\mathrm{B} \& \mathrm{R}$ jakkolwiek przynosi pewne rezultaty, okupiona jest jednak marnotrawstwem.

Patrząc z perspektywy doświadczeń krajów, które wyszły z grupy aspirantów i uzyskały trwałą obecność w grupie liderów innowacyjnej gospodarki, wydaje się, że przejście od gospodarki niskiego potencjału do gospodarki wysokiego potencjału innowacyjnego wymaga uporządkowania kilku ważnych spraw:

- minimalizacji napięć pomiędzy cyklem politycznym a czasem koniecznym na uzyskanie efektów rozwojowych poprzez porozumienie elit politycznych i gospodarczych oraz uzgodnienie długookresowej strategii;

- poważnych inwestycji $\mathrm{w} \mathrm{B} \& \mathrm{R}$, prawdopodobnie na poziomie $2.5 \% \mathrm{PKB}$ i wspomaganego przez państwo rozwoju potencjału badawczego w korporacjach; chodzi tu o aplikacyjną orientację pozwalającą na przyśpieszone efekty badań naukowych;

- rozwoju systemu edukacyjnego ukierunkowanego na twórczość, nauki ścisłe, technologię i współpracę między ludźmi;

- mobilizacji społeczeństwa, opinii publicznej w kierunku rozwoju innowacyjności w życiu publicznym i gospodarce; wymaga to poważnego wysiłku propagandowego, instytucji i nakładów finansowych ${ }^{5}$.

5 Ten niezwykle istotny problem wykracza poza ramy tego rozdziału. Warto jednak zasygnalizować kluczowe znaczenie tzw. Sputnik moment - mobilizacji Stanów Zjednoczonych w obliczu wprowadzenia na orbitę radzieckiego Sputnika. 


\subsection{Praktyka zarządzania procesem innowacyjnym}

Wysoki odsetek nieudanych prób modernizacyjnych wynika w naszym przekonaniu z nadmiernego koncentrowania się na tym „co zrobić”, przy jednoczesnym niedostatecznym skupieniu się na pytaniu ,jak zrobić”.

Pytanie „co zrobić” nie tylko sprzyja „mierzeniu siły na zamiary”, lecz także prowadzi nieuchronnie do mnożenia zadań przez grupy interesów, biurokrację i polityków. Praktyka ta w swej istocie nie różni się od praktyki „podczepiania pod plan" znanej z gospodarki planowej. Działanie takie znakomicie ułatwia fakt, że liczne zadania dadzą się uzasadnić jako społecznie i ekonomicznie ważne (i takimi są w znacznej liczbie przypadków). W efekcie końcowym, program modernizacyjny cieszy się szerokim poparciem, lecz ma małą szansę realizacji ze względu na nieadekwatne zasoby materialne i ludzkie.

Pytanie, ,jak zrobić” wymaga krytycznej pogłębionej oceny dostępnych możliwości dla konkretnego kraju w określonym czasie. Trudność odpowiedzi polega na tym, że zakres możliwości jest węższy niż zakres wyznaczony przez diagnozę „co zrobić” i wymaga zawężenia liczby priorytetów, naruszającego tym samym oczekiwania poszczególnych grup interesów.

Pierwszym krokiem ku „co zrobić” jest realistyczna ocena miejsca kraju na globalnej mapie konkurencyjności w stosunku do innych krajów budujących swą przewagę na innowacyjności, nie zaś na niskich kosztach. Trzeba realistycznie ocenić swoje obecne miejsce na globalnej mapie konkurencyjności i szanse awansu. Mówiąc kolokwialnie, trzeba ocenić, w której lidze się obecnie gra i w której można by grać za kilka sezonów, awansując lub spadając w rankingu.

O wartości nawet najlepiej pomyślanego i społecznie akceptowanego programu modernizacyjnego decyduje jego realizacja, a to z kolei wymaga odpowiedniego continuum kadr - od szeroko rozumianego aparatu państwa, przez samorządy lokalne, do organizacji społeczeństwa obywatelskiego.

Sprawność aparatu w decydującym stopniu wyznacza jego stabilność i odpolitycznienie urzędników wybranych w oparciu o kryteria merytoryczności i uczciwości. Znaczenie aparatu urzędniczego państwa w zarządzaniu gospodarką jest szczególnie ważne, ale i złożone w przypadku realizacji polityki innowacyjnej. W przypadku kadr realizujących politykę innowacyjną ocena skuteczności kadry urzędniczej jest trudniejsza niż w innych obszarach działania państwa ze względu na „słabą algorytmiczność” takiej oceny oraz znaczny odstęp czasowy między działaniami a ich rezultatami. Istnieje podstawowa sprzeczność między cechami dobrej administracji - postępowania według standardowych reguł i unikania ryzyka - a innowacjami, z definicji zakłócającymi zastany porządek i obciążonych znacznym i słabo zdefiniowanym ryzykiem powodzenia. Stąd pokusa oceny 
na podstawie realizacji nakładów, np. wydania państwowych pieniędzy na $B \& R$, może prowadzić do marnotrawstwa środków i, co gorsze, tworzenia ,potiomkinowskich wiosek" dających fałszywe poczucie sukcesu.

Stworzenie kadry urzędniczej spełniającej te warunki to dopiero pierwszy krok. W sprawnym systemie administracji zachowania urzędników są w znacznym stopniu kształtowane nie przez ich osobiste przymioty, a przez środowisko instytucjonalne - system zasad i motywacji, które powodują lub zakazują określonych działań. Zasady i przepisy, formalne i nieformalne, wspólnie definiują strukturę zachęt urzędników w określonej organizacji lub w sektorze publicznym jako całości. Obszar polityki innowacyjnej wymaga od urzędników wyjścia poza standardowy zakres oczekiwanych cech osobowościowych - niezbędny jest komponent zachowań biznesowych, np. zdolności podejmowania ryzyka oraz akceptacji zmniejszania w czasie roli administracji w danym obszarze.

Badania sprawności administracji pokazują, że niezależnie od państwa, na poziomie indywidualnych motywacji, aby dobrze wypełniać swoje obowiązki (w rozumieniu oczekiwań ze strony systemu), urzędnicy muszą widzieć związek między swoim wysiłkiem a przyszłą oceną ich pracy. Trwałość i konsekwencja tych związków kształtowane są przez środowisko instytucjonalne, w którym pracują (Manning, Mukherjee i Gokcekus, 2000). Jednakże związek między zachowaniami urzędników a instytucjonalnym środowiskiem nie jest deterministyczny. W tym samym otoczeniu niektórzy urzędnicy pracują nieudolnie (przy czym na ogół jest to wyuczona nieudolność, a nie wynik ich wrodzonej nieudolności), niektórzy wykorzystują swoją pozycję dla pozyskiwania ubocznych dochodów, w tym korupcyjnych, inni pracują sprawnie, mając jako priorytet interes publiczny. Możemy więc raczej mówić o przewadze pewnych zachowań w danym otoczeniu niż o wszechogarniającej regule.

Znajomość warunków sprawnego funkcjonowania administracji nie oznacza jednak automatycznie zdolności zreformowania samej administracji. Bank Światowy ocenia, że mniej niż połowa projektów wspierających reformy administracyjne zakończyła się sukcesem. Wśród przyczyn tak niskiej efektywności interwencji mających za cel wprowadzenie sprawniejszych i bardziej przystających do potrzeb współczesnego społeczeństwa systemów zarządzania publicznego Bank Światowy wskazuje na zbytnio zawężony, technokratyczny punkt widzenia na temat tego, co jest potrzebne $\mathrm{w}$ reformach sektora publicznego oraz zbytnie poleganie na „najlepszych praktykach” przenoszonych z krajów rozwiniętych, a często niemożliwych do wdrożenia w krajach rozwijających się. Warunkiem poprawy efektywności reform administracji publicznej powinna być „praca z lokalnymi partnerami dla lepszego zrozumienia i uwzględnienia szerokiej gamy motywacji i nacisków - zarówno wewnątrz, jak i na zewnątrz wła- 
dzy - które mają wpływ na funkcjonowanie administracji publicznej” (Manning, Mukherjee i Gokcekus, 2000, s. 1).

Problemem o kluczowym znaczeniu jest funkcjonalna relacja między światem polityki (rządzenia) i światem administracji (zarządzania). Polityczna atrakcyjność klientelizmu oraz zagrożenie korupcją w obszarach zamówień publicznych, państwowych subsydiów, podziału etatów w organizacjach państwowych i samorządowych powoduje, że szczególnego znaczenia nabiera stworzenie „chińskiego muru" między administracją a światem polityki. Dotyczy to administracji państwowej, ale może nawet w większym stopniu administracji samorządowej, gdzie granica między rządzeniem a zarządzaniem jest płynna (World Bank, 2008).

Tradycyjną metodą takiego oddzielenia administracji od polityki jest tworzenie służby cywilnej. Koncepcja ta wspiera się na dwóch filarach: merytorycznej kompetencji oraz stabilizacji zawodowej. Tak wybrani urzędnicy służby cywilnej są lojalni wobec interesu państwa ponad bieżącymi interesami partii rządzącej.

Historycznie wyłonienie służby cywilnej w krajach transformacji, w tym w Polsce, wymagało zmierzenia się z problemem „grzechu pierworodnego” - stabilizacji pierwszej generacji urzędników służby cywilnej - a więc ludzi pochodzących z systemu, który okazał się niesprawny administracyjnie. Na początku transformacji istniało ryzyko stabilizacji urzędników, którzy nie tylko zostali ukształtowani w systemie niesprawnym, lecz także szybko tracących merytoryczne kwalifikacje (pomijamy sprawę lojalności wobec nowego ładu politycznego) ${ }^{6}$. $\mathrm{Na}$ dodatek, akceleracja zmian zachodzących w gospodarce i społeczeństwie prowadzi do dodatkowego problemu funkcjonowania służby cywilnej - szybkiej deprecjacji merytorycznej wiedzy urzędników. Model „mandarynów administracji” był adekwatny do zarządzania w stabilnym otoczeniu. W czasach szybkich zmian niezrozumienie nowych technologii oraz społecznych zachowań i trendów może wręcz prowadzić do działań obstrukcyjnych, antyinnowacyjnych.

Niewątpliwą słabością polskiej administracji jest brak służby cywilnej, a więc klasy urzędniczej wybranej według kryteriów merytorycznych i niepodlegającej

$6 \quad$ Historycznie, problem ten rozwiązywano na różne sposoby. Przykładowo, w Wielkiej Brytanii istniała klasa właścicieli ziemskich (landed gentry), która dzięki zasadzie niepodzielności majątków ziemskich „wypychała” osoby dobrze przygotowane merytorycznie do służb cywilnej i kolonialnej. W kontynentalnej Europie służba cywilna była narzędziem sprawowania władzy „oświeconego" monarchy absolutnego. Systemy te zostały też odpowiednio przeniesione do dawnych kolonii. Specyficzny model przyjęły klasyczne Chiny, gdzie czynnik merytoryczny wyboru urzędników niezależnie od klasy był dominujący (słynne egzaminy znajomości tysięcy znaków pisma). Jednakże, w żadnym historycznym przypadku klasa służby cywilnej nie powstała w środowisku demokratycznego sprawowania władzy. Z tej też przyczyny Stany Zjednoczone w znacznie mniejszym stopniu niż inne kraje Zachodu opierają administrację na służbie cywilnej, a w znacznie większym na politycznych nominatach. 
wymianie wraz ze zmianą partii rządzącej. Następujące po sobie partie rządzące dążyły do wymiany kadry służby cywilnej na lojalną wobec polityków, „falandyzując" ustawowe podstawy służby cywilnej, np. przez wprowadzenie zasady „pełniącego obowiązki” lub poprzez rezygnację z zasady konkursowego naboru. Potrzeba wynagrodzenia sojuszników partyjnych i zwyczajny nepotyzm nie były bez znaczenia. „Każdy rząd - wbrew zasadom służby cywilnej - przygotowuje i forsuje swój projekt ustawy, dla siebie, ale kiedy zaczyna on obowiązywać, rząd musi swe miejsce oddać następnemu. Można powiedzieć, że każdy z nich gotuje byt następnemu... Obywatele są ofiarami stałej atmosfery zagrożenia i niepewności” (Górzyńska, 2009, s. 198). Opinia ta jest niestety nadal aktualna.

W przypadku Polski trudność zbudowania administracji zdolnej zarządzać procesem innowacyjnym trzeba zderzyć z faktem bezprecedensowego wzrostu, w ostatnich dwóch dekadach, liczby absolwentów uczelni kierunków wymaganych w sprawnej administracji: ekonomii, prawa, zarządzania i administracji. W początkowym okresie transformacji opcja pracy w administracji przegrywała z otwierającymi się możliwościami w prywatnym biznesie, znacznie atrakcyjniejszym finansowo i społecznie. Poprawa ogólnego standardu pracy w administracji oraz zwiększenie konkurencji na rynku prywatnym spowodowały, że „praca w urzędzie" staje się rozważaną alternatywą dla młodych absolwentów uczelni. Potwierdza to tezę o upolitycznieniu zatrudnienia w administracji, ale również spółkach handlowych pod bezpośrednia kontrolą rządu i samorządów. Mając dostęp do wykształconych absolwentów, polska klasa polityczna nie musi budować z nich sprawnego, uniwersalnego politycznie aparatu urzędniczego.

Postępujące przesunięcie punktu ciężkości działań innowacyjnych z przestrzeni działań indywidualnych na styku nauka - przedsiębiorstwo do działań w przestrzeni społecznej wymaga zaistnienia nowego typu partnera dla administracji państwowej w prowadzeniu polityki proinnowacyjnej - możliwie szerokiego i zróżnicowanego wachlarza organizacji społeczeństwa obywatelskiego: od zrzeszeń producentów, przez niezależne ośrodki badawcze (think tanks), do organizacji charytatywnych. Doświadczenie krajów wysoko rozwiniętych potwierdza rosnącą rolę rozwojową, jaką odgrywają organizacje pozarządowe, w szczególności co do:

- pośrednictwa między administracją a obywatelami - z jednej strony, co do przekazu aspiracji, pytań i proponowanych alternatyw obywatelskich, z drugiej zaś - co do przekazu zamierzeń i działań rządowych w sposób zrozumiały dla obywateli; funkcja „przekładania” zamierzeń administratora polityki gospodarczej będzie miała coraz większe znaczenie, ponieważ coraz liczniejsze obszary polityki gospodarczej nie mogą być ocenione bezpośrednio przez obywateli i wymagają profesjonalnej, lecz niezależnej oceny; 
- społecznej kontroli działań administracyjnych (accountabiity), co do ich przejrzystości i wykorzystania środków;

- dostarczania usług, takich jak szkolenia, kwalifikowanie beneficjentów polityki itd.

Tkanka organizacji społecznych jest w Polsce ciągle niewystarczająco rozwinięta. Działalność taka nadal kojarzy się Polakom bardziej z bohaterami Żeromskiego niż systematyczną i pragmatyczną kontrybucją na rzecz swojego otoczenia niewymagającą jednak szczególnych życiowych poświęceń.

Bogato ustrukturyzowane społeczeństwo obywatelskie z gęstą siecią organizacji nie nastawionych na zysk, a obsługujących różnorodność społeczeństwa, to właściwość kultury protestanckiej (mając świadomość znacznego uproszczenia tej oceny). Niewątpliwą przyczyną słabego rozwoju systematycznej działalności organizacji społecznych w latach transformacji było pojawienie się możliwości polepszania dobrobytu swojej rodziny i bliskich przez zwiększony wysiłek zawodowy, bezpośrednio konkurujący o ten sam budżet czasowy z aktywnościami na rzecz „obcych”. Pojawiła się też możliwość okazjonalnej działalności charytatywnej (jak WOŚP), zjawisko pozytywne samo w sobie, ale dające ludziom usprawiedliwienie dla słabego uczestnictwa w organizacjach społecznych. Rolę odegrało też bez wątpienia złe doświadczenie organizacji pseudospołecznych czasu komunizmu. Jeszcze innym wymiarem tego zjawiska jest trwałość cech kulturowych.

Aktywność społeczna wspierająca działania modernizacyjne utrzymuje się od kilku lat na podobnym poziomie bez tendencji wzrostowych. Aktywna jest około $1 / 3$ społeczeństwa. W wolontariat w ramach formalnych organizacji zaangażowana jest $1 / 5$ jedna piąta, a w działania na rzecz osób spoza kręgu rodziny i znajomych lub na rzecz okolicy około $1 / 4$ społeczeństwa7 (Adamiak, 2014).

\section{Uczestnictwo w gospodarce światowej}

W dającej się przewidzieć przyszłości będziemy wystawieni na coraz to brutalniejszą konkurencję w zglobalizowanej gospodarce zarówno o zasoby, jak i o rynki zbytu. Wpływa na to w pierwszej kolejności czynnik geopolityczny - rozszerzenie obszaru konkurencji o zasoby podażowe i rynki zbytu ze strony

7 Odsetek badanych deklarujących zaangażowanie w wolontariat na rzecz organizacji o charakterze charytatywnym jest prawdopodobnie zawyżony, część badanych mogła bowiem za wolontariat uznać materialne wspieranie tych organizacji. 
krajów dotychczas niebędących istotnymi podmiotami gospodarki światowej. Czynnik geopolityczny jest w sposób rewolucyjny wzmacniany przez nowe technologie obniżające koszty transakcyjne przemieszczania ludzi, rzeczy i informacji, a przez to pozwalające na tworzenie globalnych elastycznych łańcuchów produkcji - nowych reguł alokacji kapitału.

\subsection{Polska wobec wyzwań konkurencji globalnej}

W nowych warunkach zmianie ulegają też sposoby konkurencji, które dadzą Polsce szanse polepszenia swej pozycji w gospodarce globalnej. Dotychczas rozwój oparty na produkowaniu więcej tego samego, w najlepszym przypadku ze zmianą technologii prowadzącą do obniżki kosztów, był dominującą strategią rozwojową. W polskiej gospodarce nastąpiły, co prawda, poważne zmiany technologiczne i organizacyjne, nośnikiem których były nowe metody wytwarzania wdrażane do firm przez nowych, na ogół zagranicznych właścicieli przedsiębiorstw (prywatyzowanych i greenfield). Innowacyjność technologiczna i organizacyjna nie wynikała jednak z oryginalnych polskich wynalazków czy też presji polskich przedsiębiorców na ich wdrożenie. Miała miejsce w wyniku absorpcji technologii i rozwiązań organizacyjnych wynalezionych poza Polską, z reguły będących innowacyjnymi imitacjami w stosunku do zagranicznych firm matek.

Na ogół zagraniczni właściciele przedsiębiorstw zatrzymywali dobrze przygotowanych pracowników, rynek produktu, jak również markę produktu, a następnie modernizowali proces produkcji przez wprowadzenie nowych maszyn, doskonalili design produktu oraz marketing. Był to bierny proces niejako wtłaczania innowacji w gospodarkę. Przykładem może być rynek produktów mlecznych, gdzie pod starymi nazwami i smakami produktów kryje się często nowa technologia ich produkcji, pozyskania surowców i dystrybucji - ograniczająca koszty, w tym zatrudnienia.

Autonomiczny popyt na innowacje związany był z niejako organicznym odreagowaniem na nieudolność systemu gospodarki planowej. W czasie transformacji Polska doświadczyła prawdziwej eksplozji małych firm, zjawisko szeroko podziwiane na świecie jako dowód na naturalną potrzebę samorealizacji gospodarczej w warunkach gospodarki rynkowej. Transformacja stworzyła dostatecznie dużo przestrzeni dla idącej w miliony grupy ludzi przedsiębiorczych. Nowi przedsiębiorcy, zakładając małe firmy, siłą rzeczy kupowali nowe maszyny i technologie, bardziej wydajne w porównaniu z istniejącymi uprzednio, nawet jeśli z drugiej ręki po kilku latach używania na zachodzie. W polskich warunkach był to ciagle olbrzymi skok innowacyjny (podobnie jak pięcioletni Mercedes jest ciaggle znacznie lepszy niż nowa Łada). 
Modernizacja oparta na „wypełnianiu luk” odziedziczonych z przeszłości ma oczywiście swoje ograniczenia - jej moc sprawcza wygasa wraz z usunięciem niesprawności starego systemu.

Dotychczasowa modernizacja dawała jedynie pośrednie wzmocnienie konkurencyjności gospodarki polskiej - zastąpienie lokalnymi produktami produktów importowanych ${ }^{8}$. Nie tworzyła jednak możliwości konkurencji na rynkach globalnych. Rozwój przez wchodzenie na wyższe poziomy w łańcuchu tworzenia wartości produktu oraz zmiany struktury gospodarki polegające na zwiększaniu udziału sektorów o większej produktywności i unikalności, to oczywiście najlepsza droga modernizacji, dająca największe szanse wzrostu produktywności i konkurencyjności w wymiarze nie tylko poszczególnych przedsiębiorstw, lecz także całej gospodarki i społeczeństwa. Jest to, mimo postępu ostatnich lat, wciąż w niezbyt znacznym zakresie przypadek Polski.

\subsection{NES wobec wyzwań konkurencji globalnej}

Wielką pokusą państwowych modernizatorów jest protekcjonizm gospodarczy. Dotyczy to zarówno ochrony starych przemysłów, jak i przemysłów raczkujących (infant industries). O ile taki model modernizacji mógł mieć sens jeszcze w XX wieku, o tyle nie ma go (a co ważniejsze instrumentów) w dobie wolnego handlu i pojawiania się innowacyjnych substytutów produktowych ${ }^{9}$.

Protagoniści NES są świadomi niepowodzeń aktywizmu modernizacyjnego państwa opartego na protekcjonizmie. W szczególności wyciągnięto wnioski z niepowodzenia popularnej w krajach Ameryki Łacińskiej w latach 60. i 70. $\mathrm{XX}$ wieku polityki substytucji importu, polegającej na wspieraniu krajowych producentów oferujących produkty zastępujące produkty z importu. Polityka ta, uzasadniana chęcią przyśpieszonej modernizacji, przyniosła skutki odwrotne do oczekiwanych. Pomimo krótkoterminowych korzyści, takich jak wzrost zatrudnienia i stworzenie ograniczonej ilości lepiej płatnych miejsc pracy, brak kon-

$8 \quad$ Przykładem może być wyparcie zagranicznych produktów spożywczych, masowo wchodzących na polski rynek w początkowych latach transformacji, przez produkty polskie, dzięki zwiększeniu ich atrakcyjności.

9 Rozgrywający się na naszych oczach dramat protekcjonizmu spod znaku America first czy francuskiej obrony przed „dumpingiem socjalnym” może mieć daleko idące konsekwencje dla programu innowacyjnej modernizacji w krajach, takich jak Polska. Symptomatyczna była reakcja E. Macrona na plany firm Whirepool przeniesienia produkcji z Francji do Polski. „Macron rozmawiał z regionalnym dziennikiem północnej Francji po środowym spotkaniu w Amiens ze strajkującymi pracownikami zakładów Whirlpool, które zostaną zamknięte ze względu na przeniesienie produkcji do Łodzi [...] W ciągu trzech miesięcy po wybraniu mnie (na prezydenta) podjęta zostanie decyzja w sprawie Polski" - powiedział Macron. Pozyskano z: https://www. bankier.pl/wiadomosc/Francja-Macron-opowiada-sie-za-sankcjami-wobec-Polski-3685431.html. 
kurencji prowadził do małej innowacyjności i niskiej produktywności, a w efekcie do wysokich cen przy słabej jakości lokalnych produktów w porównaniu z produktami z importu. Co więcej, uznaniowość protekcjonizmu prowadziła do wzrostu korupcji i pogłębienia się nierówności dochodowych (Lustig i in., 2013).

Dlatego też NES postuluje realizację programu modernizacyjnego w ramach gospodarki otwartej na wyzwania konkurencji w skali globalnej, wręcz wykorzystującej jej mechanizmy i efekty skali. Jest to propozycja oparta nie na grze zero-jedynkowej, lecz na działaniach z korzyściami dla wszystkich uczestniczących stron porozumienia. To z kolei wymaga koordynacji i kooperacji na poziomie państwowym. Przykładem takiej koordynacji ma być transgraniczny program tzw. Nowego Jedwabnego Szlaku.

Argumentem integrującym, leżącym u podstaw korzyści tak rozumianej koordynacji między państwami, ma być podobna relacja krajów doganiających w stosunkach z krajami wysoko rozwiniętymi - ich peryferyjność.

W relacji centrum - peryferie typ inwestycji, czy szerzej, międzynarodowy podział pracy ma charakter strukturalny. Zagraniczne inwestycje bezpośrednie w krajach doganiających z krajów Zachodu koncentrują się na ogół w sektorach tradycyjnych o małym stopniu ryzyka inwestycyjnego, a więc małym nasyceniu innowacjami. Inwestycje zagraniczne trafiają do sektorów o znacznym zużyciu energii i ze względów ekologicznych nietolerowanych w krajach rozwiniętych, takich jak cementownie czy stalownie oraz montowniach wykorzystujących tanią siłę roboczą (nie należy mylić montowni produktów wysokiej technologii $\mathrm{z}$ wprowadzaniem innowacji). Próby motywowania zagranicznych inwestorów do inwestowania w przedsięwzięcia innowacyjne, np. przez zaostrzenie regulacji ekologicznych, mogą prowadzić do konsekwencji odwrotnych od zamierzonych - ograniczenia napływu inwestycji do tradycyjnych sektorów i ucieczka do krajów gotowych zaakceptować warunki stawiane przez inwestorów.

Ograniczenie transferu innowacji z najwyższej półki do krajów peryferyjnych ma swoje racjonalne biznesowe podstawy. W pierwszej kolejności może być podyktowane słabszym przygotowaniem siły roboczej oraz niższymi kosztami zewnętrznymi (externalities) niż w krajach pochodzenia kapitału. Jakkolwiek siła robocza w Polsce może mieć (i często ma) wyższe formalne wykształcenie niż siła robocza w krajach rozwiniętych, jednak dla inwestora decydujące znaczenie ma wiedza praktyczna (tacit knowledge), a tę zdobywa się w praktyce, naśladując mistrzów zawodu oraz uczestnicząc w grupie pracowniczej. Są to zdolności trudne do przeniesienia między krajami czy społecznościami i nabywane latami. Wymagania wiedzy praktycznej są tym powszechniejsze i łatwiejsze do zdobycia, im niżej technologicznie w łańcuchu produkcji jest ulokowana działalność. 
Wyśrubowane normy ekologiczne i prawa pracy w krajach rozwiniętych są istotną przyczyną przenoszenia elementów działalności gospodarczej niespełniających tych norm do krajów gotowych do akceptacji mniej ostrych norm. Motywem lokalizacji jest więc możliwość eksternalizacji kosztów związanych z przestrzeganiem norm. Dotyczy to w znaczącym stopniu „brudnych” elementów łańcucha produkcji, z reguły o najmniejszym nasyceniu wysoką technologią i najmniej innowacyjnych.

Nie można też pomijać faktu, iż najnowsze, najbardziej innowacyjne produkty i technologie decydujące o przewadze konkurencyjnej są pod najściślejszą ochroną przedsiębiorstw, które je wytwarzają. Dlatego patrzą one z dużą podejrzliwością na propozycje ulepszeń proponowane przez podwykonawców z krajów peryferyjnych - ryzyko utraty monopolu w zakresie ulepszania produktu jest nieraz oceniane jako większe niż korzyści wynikające z możliwości obniżki kosztów.

W ograniczaniu przepływu innowacji centrum - peryferie istotną rolę odgrywają również czynniki pozabiznesowe. Zagraniczne korporacje w razie ograniczeń globalnego popytu są pod wielkim naciskiem politycznym - któremu często ulegają - do przeniesienia produkcji umiejscowionej wysoko w łańcuchu tworzenia wartości z kraju peryferyjnego do kraju pochodzenia inwestora. Kwestia tak zwanej narodowości kapitału, czy raczej ulegania zagranicznych właścicieli politycznym naciskom krajów ich pochodzenia, powróciła ze wzmożona siłą w następstwie kryzysu 2008 roku. Efektem likwidacji w kraju peryferyjnym produkcji o dużym nasyceniu nowoczesnymi rozwiązaniami innowacyjnymi jest niekorzystna zmiana struktury gospodarki na mniej innowacyjną oraz zmniejszenie puli dobrze płatnych miejsc pracy. W dłuższej perspektywie oznacza to likwidację miejsc zdobywania przez pracowników wiedzy praktycznej, co odbija się niekorzystnie na społecznej zdolności budowy potencjału innowacyjnego w skali całej gospodarki.

\section{Konkluzje}

Modernizacja gospodarki oznacza przechodzenie do modelu pozwalającego na uzyskiwanie znaczących przychodów z uczestnictwa w gospodarce światowej na wyższym poziomie łańcucha wartości w ramach istniejących sektorów gospodarki oraz zmiany struktury gospodarki polegającej na zwiększaniu udziału sektorów o wyższej produktywności i lepszej konkurencyjności globalnej.

Zadanie to nie jest łatwe, rezultaty w coraz większym stopniu zależą od umiejętności uruchomienia społecznej zdolności do innowacji jako systematycz- 
nej aktywności mającej na celu lepsze wykorzystanie dostępnych zasobów oraz lepsze zaspokajanie potrzeb, to zaś zależy od umiejętności współpracy - zawiązywania koalicji rozwojowych między państwem a przedsiębiorstwami. $\underline{\mathrm{W}}$ tym kontekście trzeba postawić pytanie, z kim ze sfery biznesu w Polsce nadchodzacych dekad państwo może tworzyć koalicję rozwojową?

Gospodarka polska jest zdominowana przez mikroprzedsiębiorstwa o zatrudnieniu do 9 osób (96\% całego zbioru). Polska gospodarka ma tylko około 3500 ( $0,2 \%$ całego zbioru przedsiębiorstw sektora niefinansowego) dużych przedsiębiorstw. Sektor dużych przedsiębiorstw jest zdominowany przez firmy państwowe i firmy kontrolowane przez kapitał zagraniczny. Wśród 10 największych firm (według wielkości sprzedaży) 54,9\% stanowią przychody spółek kontrolowanych przez państwo. Wśród krajów transformacji większy udział sektora kontrolowanego przez państwo jest tylko na Ukrainie (68,9\%) (Szarzec, 2016, s. 130). Średnia wielkość zatrudnienia w firmach kontrolowanych przez państwo wynosi 243 pracowników, przez kapitał zagraniczny 230, a przez kapitał krajowy 72 osoby. Sektor dużych firm kontrolowanych przez kapitał krajowy w zasadzie nie wzrasta, rośnie za to sektor firm kontrolowanych przez państwo (Błaszczyk, 2017).

Małe i średnie przedsiębiorstwa, mimo że stanowią trzon polskiej gospodarki w sensie proporcji zatrudnienia i kontrybucji do GDP, nie dysponują ani kapitałem, ani zasobami ludzkimi, aby w aktywny sposób uczestniczyć w rynku badań i rozwoju. Z kolei sektor przedsiębiorstw państwowych, mimo że obejmuje duże przedsiębiorstwa, ma tylko $8 \%$ przychodów z eksportu, co oznacza nieobecność na rynkach wysokiej konkurencji, które weryfikują potencjał innowacyjny.

Zagraniczne firmy w Polsce odgrywają i będą odgrywać w dającej się przewidzieć przyszłości znaczącą rolę we wprowadzaniu innowacji do polskiej gospodarki - zarówno kapitałowych, jak i bezkapitałowych. Dlatego też należy utrzymywać atrakcyjność Polski dla inwestycji zagranicznych, są one bowiem poważnym kanałem dopływu z zewnątrz nowych produktów, technologii i metod organizacji i zarządzania. Firmy zagraniczne mogą i powinny być traktowane jako ważne źródło innowacji dla polskich firm kooperantów. Wymaga to jednak umiejętnego wsparcia ze strony organów rządowych, co, jak pokazuje np. transfer technologii związanych z zakupem zachodniego uzbrojenia, nie jest zadaniem prostym.

Trzeba sobie jednak zdawać sprawę, że strategia taka oznacza dominację innowacji imitacyjnych, które są generowane i instalowane u polskich wykonawców w ramach zadań produkcyjnych zleconych z firm-matek działających globalnie. Innowacje niesuwerenne powodują dwa rodzaje ryzyka. Po pierwsze, innowacje takie mogą być wycofane z Polski w przypadku przeniesienia produk- 
cji do lokalizacji bardziej opłacalnych z punktu widzenia firmy-matki. Po drugie, innowacje niesuwerenne, na ogół ucieleśnione w importowanych maszynach, nie rozwijają miejscowego potencjału innowacyjnego, na przykład przez z wielu względów niemożliwą dla Polski odwróconą inżynierię, która leżała u podstaw początkowych sukcesu krajów dalekiego wschodu.

Coraz popularniejszym obszarem aktywizmu gospodarczego państwa jest wspieranie startupów, szczególnie w modnych obszarach, takich jak biochemia czy informatyka. Jest to działanie ważne, chociażby dla wyzwalania „społecznej energii innowacyjnej", popularyzacji sukcesu opartego na talencie i wiedzy jako głównego koła napędowego nowoczesnych gospodarek. Trzeba jednak pamiętać, że dla przejścia od startupu do implementacji potrzebny jest cały biznesowy ekosystem, którego w Polsce niestety brak. Stąd też, zwiększając zaangażowanie państwa w rozwój startupów, nie należy oczekiwać ich istotnego wpływu na gospodarkę.

Kierunkiem modernizacyjnej koalicji rozwojowej, z którym obecny rząd wiąże największe nadzieje, ale również wywołującym największe kontrowersje, jest wykorzystanie dużych spółek (firm) kontrolowanych własnościowo przez Skarb Państwa. Uzasadnieniem formułowanym explicite jest fakt, że tylko te „niezagraniczne” firmy dysponują znaczącymi zasobami kapitałowymi niezbędnymi do realizacji kapitałochłonnych programów modernizacyjnych (jak np. centralny port lotniczy). Uzasadnieniem implicite jest łatwość „przekonania" zarządu tych spółek do inwestowania w wybrane programy. W przypadku spółek SP jest naturalnym odruchem odwołanie się do dominacji administracyjno-politycznej, jedynie formalistycznie ukrytej pod płaszczykiem interwencji właścicielskich. Ten zarzut odnosi się w jeszcze większym stopniu do przedsiębiorstw kontrolowanych przez samorządy, gdzie pokusa nepotyzmu i korupcji jest silniejsza ze względu na słabszą kontrolę społeczną ${ }^{10}$.

Sukces wykorzystania zasobów kapitałowych spółek SP w procesie modernizacji gospodarki wymaga kombinacji: (1) doboru kadr zarządzających na podstawie kryteriów czysto merytorycznych; (2) przestrzegania dobrych praktyk korporacyjnych (corporate governance) w szczególności wykluczenia interwencji „na telefon”; (3) profesjonalnego zewnętrznego systemu oceny (audytu) spółek.

10 W polskim prawodawstwie konstrukcja spółki SP pojawiła się w ustawie o prywatyzacji z 1990 roku (którą autorzy współtworzyli). Oryginalnym zamiarem było nadanie dużym przedsiębiorstwom państwowym „w kolejce do prywatyzacji” formy rynkowej. Z perspektywy lat było to myślenie naiwne, niedoceniające politycznych interesów skupiających się wokół tych spółek. Tyle że alternatywy były także ułomne. Pokazała to prywatyzacja zarówno w Rosji, jak i Czechosłowacji. 
W efekcie tych ograniczeń, w przeciwieństwie do azjatyckich przykładów sukcesu, w Polsce polityka oparta na sugestiach NES nie ma oczywistego kandydata do tworzenia koalicji rozwojowej. Jest to najpoważniejsze ograniczenie tej koncepcji jako sugestii dla tworzenia strategii doganiania.

W tym kontekście lepsze zbalansowanie aktywności gospodarczej przez wzmocnienie współpracy z innymi krajami doganiającymi ma sens. W pierwszej kolejności, strategiczny pragmatyzm zaleca obecności na maksymalnie wielu rynkach, szczególnie w czasie daleko idących zmian w globalnym porządku gospodarczym. Gospodarka polska jest w znaczącym (według nas nadmiernym) stopniu zależna od gospodarki niemieckiej (1/4 eksportu). Jest to szczególnie istotne przy oczekiwanych szansach eksportowych na rynkach regionu Azji i Pacyfiku, które stają się najbardziej dynamicznym regionem wzrostu klasy średniej i związanego z tym popytu. W roku 2015 wydatki konsumpcyjne (PPP, w USD 2011 r.) USA stanowiły 4,7 biliona dolarów co stanowiło $13 \%$ światowych wydatków konsumpcyjnych, a dla Chin wynosiły 4,2 biliona dolarów, co stanowiło $12 \%$ światowych wydatków konsumpcyjnych, dla Niemiec odpowiednio 1,5 bilionów dolarów i $4 \%$ światowych wydatków. Prognozowane wielkości dla roku 2030 wynoszą odpowiednio: dla USA 4,7 bilionów dolarów i 7\% światowych wydatków konsumpcyjnych, dla Chin 14,3 bilionów dolarów i 22\%, Niemiec 1 bilion i 2\% (Kharas, 2017).

Trzeba mieć jednak świadomość, że aspiracje modernizacyjne Polski mogą kolidować z interesami gospodarek i firm zarówno centrum, jak i peryferii; tak na poziomie strategicznym, jak i w konkretnych przypadkach. Model uczestnictwa $\mathrm{w}$ gospodarce światowej realizował się dotychczas przez relacje z inwestorami centrum. NES z jej zredefiniowaną rolą państwa i narodowego interesu, z jednej strony prowadzi do zredefiniowania współpracy z tradycyjnymi partnerami zachodnimi w kierunku większej selektywności oraz warunków inwestowania (np. wakacji podatkowych). Z drugiej zaś - wymaga nowych umiejętności prowadzenia polityki gospodarczej w warunkach innej kultury współpracy oraz asymetrii potencjału partnerów ${ }^{11}$.

Polskie firmy zaczynają wchodzić na rynek światowy, gdzie znajdują się pod wielką konkurencyjną presją premiującą technologie i produkty najnowsze. Toteż firm takich jest niewiele, za to dużo jest firm, które współpracują z największymi światowymi koncernami prowadzącymi działalność na skalę globalną. Tak dzieje się choćby w przemyśle samochodowym. Ci kooperanci też są pod presją: poszukiwania nowych metod zarządzania, produkcji, szkolenia pracowników, podnoszenia jakości. Pośrednio bowiem, podobnie jak koncerny dla

11 Symptomatyczna jest formuła „1+16” współpracy między Chinami a 16 państwami Europy Środkowo-Wschodniej - ludność „16” to mniej niż 10\% ludności Chin. 
których pracują, konkurują na rynkach światowych. To sprzyja innowacyjności uzupełniającej. Dotyczy to przede wszystkim możliwości wzrostu firm średnich o polskim kapitale i oryginalnych polskich produktach i technologiach. Pojawia się pytanie, na ile państwo może świadomie „hodować” duże firmy oparte na polskim kapitale? Wydaje się, że korzystanie z oligarchicznych wzorów Azji napotkało by barierę społecznej nieufności mającej swe źródła w tworzeniu fortun w czasach burzliwej transformacji. Fortuny te nazbyt często powstawały bowiem w wyniku niejasnych związków miedzy aparatem państwa a biznesmenami (mimo że w Polsce praktyki te były znacznie rzadsze niż w byłym ZSRR).

$\mathrm{W}$ ostatecznym rozrachunku decydujące znaczenie dla sukcesu modernizacyjnego Polski będzie miało promodernizacyjne nastawienie przedsiębiorców, pracowników i konsumentów (a więc całego społeczeństwa). Aparatura Nowej Ekonomii Strukturalnej może być pomocna we wzmocnieniu roli państwa w sprostaniu wyzwaniom stojącymi przed gospodarką polską, trzeba jednak mieć świadomość, że zastosowanie NES może zderzyć się z wieloma istotnymi wyzwaniami i ograniczeniami. Po pierwsze, duże firmy potrzebne do tworzenia innowacyjnej koalicji rozwojowej są albo własnością korporacji zagranicznych albo pozostają własnością państwa. Po drugie, nieliczne polskie małe i średnie firmy rosną dostatecznie duże, aby podjąć wysiłek konkurencji globalnej. Po trzecie, społeczeństwo, a w tym i przedsiębiorcy, odnosi się nieufnie do instytucji państwa, a państwo z dużą nieufnością podchodzi do publiczno-prywatnych przedsięwzięć. I wreszcie, po czwarte, Polacy po latach niedoboru chcą konsumować, a nie oszczędzać, tym samym nie są podatni na obietnice poprawy przyszłego poziomu życia w zamian za zdyscyplinowane służenie interesom państwa i korporacji.

Dlatego też dalsza modernizacja gospodarki polskiej będzie wypadkową ograniczeń społecznych, politycznych i międzynarodowych oraz motywacji rozwojowych społeczeństwa. W systemie międzynarodowego krążenia towarów, usług, pieniędzy i ludzi czeka nas seria przystosowań, których charakter trudno dziś przewidzieć. Główne wyzwanie wewnętrzne stanowią sekularne zmiany demograficzne: starzenie społeczeństwa oraz spadek aktywności zawodowej. Paradoksalnie, przejście do rynku pracownika może okazać się silnym motywatorem dla przedsiębiorców do pracooszczędnych innowacji technologicznych i zarządzania.

Indywidualne motywacje konsumpcyjne społeczeństwa w Polsce są bardzo wysokie, natomiast motywacje na rzecz tworzenia form współkształtowania z państwem polityki rozwoju wydają się być niedostateczne. Rezultatem jest dominacja państwa w artykulacji celów i kierunków rozwoju, przy słabej partycypacji podmiotów gospodarczych i społecznych. Dla państwa pragnącego realizo- 
wać bardziej aktywną rolę gospodarcza zgodnie z zaleceniami Nowej Ekonomii Strukturalnej, może oznaczać to pułapkę błędnych, bo niepoddanych ocenie zewnętrznej, priorytetów polityki gospodarczej, jak również doboru niewłaściwych metod i ludzi do ich realizacji. „Przed porażką - wyniosłość, duch pyszny poprzedza upadek". Ta mądrość króla Salomona powinna wisieć nad biurkiem każdego urzędnika realizującego politykę NES ${ }^{12}$.

\section{Bibliografia}

Adamiak, P. (2014). Zaangażowanie społeczne Polek i Polaków. Wolontariat, filantropia, 1\% $i$ wizerunek organizacji pozarzadowych. Raport z badania 2013. Warszawa: Stowarzyszenie Klon/Jawor.

Błaszczyk B. (2017). Zmiany w systemie instytucjonalnym polskiej gospodarki. Wypieranie własności prywatnej rynku przez państwo w ramach „Dobrej Zmiany”. W: W. Gadomski (red.), Raport: Perspektywy dla Polski. Polska gospodarka w latach 2015-2017 na tle lat wcześniejszych i prognozy na przysztość. Warszawa: FOR. Pozyskano z: perspektywy.for. org.pl/wp-content/uploads/2017/11/Raport_Perspektywy_internet.pdf.

Górzyńska, T. (2009). Służba cywilna w Polsce: Problemy z tradycją, problemy z przyszłością. W: J. Supernat (red.), Między tradycja a przyszłościa $w$ nauce prawa administracyjnego. Księga jubileuszowa dedykowana Profesorowi Janowi Bociowi (s. 189-199). Wrocław: Wydawnictwo Uniwersytetu Wrocławskiego.

Jędrzejczak, G. i Sterniczuk, H. (2017). Nowa Ekonomia Strukturalna a polskie wyzwania rozwojowe. W: J.Y. Lin, A.Z. Nowak (red.), Nowa Ekonomia Strukturalna wobec krajów mniej zaawansowanych. Warszawa: Wydawnictwo Naukowe Wydziału Zarządzania UW.

Kharas, H. (2017). The Unprecedented Expansion of the Global Middle Class, Global Economy \& Development, Working Paper, 100, February. Washington, DC: The Brookings Institution.

Lustig, N., Lopez-Calva, L.F. i Ortiz-Juarez, E. (2013). Deconstructing the Decline in Inequality in Latin America. Policy Research Working Paper, No. 6552. Washington, DC: World Bank. Pozyskano z: https://openknowledge.worldbank.org/handle/10986/15915.

Manning, N., Mukherjee, R. i Gokcekus, O. (2000). Public Officials and Their Institutional Environment: An Analytical Model for Assessing the Impact of Institutional Change on Public Sector Performance. Policy Research Working Paper, No. 2427. Washington, DC: World Bank. Pozyskano z: https://openknowledge.worldbank.org/handle/10986/19797.

Mazzucato, M. (2013). The Entrepreneurial State Debunking Public vs. Private Sector Myths. London-New York-Delhi: Anthem Press.

Mracek, K. (2012). Middle-Class Spenders Will Lead Global Growth. Washington, DC: Kiplinger Washington Editors Inc. Pozyskano z: https://www.kiplinger.com/article/business/T019-C021-S001-middle-class-spenders-will-lead-global-growth.html.

Nipperdey, Th. (1998). Deutsche Geschichte 1800-1866. Bürgerwelt und starker Staat. Munich: Verlag C.H. Beck.

12 Księga Przysłów, 16,18, przekład Biblia Tysiąclecia. 
PARP. (2017) Raport o stanie sektora małych i średnich przedsiębiorstw w Polsce 2017. Warszawa: PARP. Pozyskano z: parp.gov.pl/images/PARP_publications/pdf/raport $\% 20$ o\%20stanie \%20sektora\%20msp\%20w\%20polsce_2017.pdf.

Rosenstein-Rodan, P. (1943). Problems of Industrialization of Eastern and South-Eastern Europe. Economic Journal, 53(210/211), pp. 202-11.

Struktura sektora przedsiębiorstw w Polsce na tle krajów UE. (2018). Ernst and Young. Pozyskano z: https://www.ey.com/Publication/vwLUAssets/ey-raport-polskie-przedsiebiorstwa2017-02-mikrofirmy/\$FILE/ey-raport-polskie-przedsiebiorstwa-2017-02-mikrofirmy.pdf.

Szarzec, K. (2016). Przedsiębiorstwa państwowe w krajach Europy Środkowo-Wschodniej. Studia Ekonomiczne Uniwersytet Ekonomiczny w Katowicach, 260, 125-136.

U.S. Bureau of Labor Statistics. (2018). Real GDP per Capita in the Republic of Korea (South Korea) (DISCONTINUED) [KORRGDPC], August 31. FRED, Federal Reserve Bank of St. Louis. Pozyskano z: https://fred.stlouisfed.org/series/KORRGDPC.

World Bank. (2008). Public sector reform: what works and why? An IEG evaluation of World Bank support (English). Washington, DC: World Bank. Pozyskano z: http://documents. worldbank.org/curated/en/311251468150314338/Public-sector-reform-what-works-andwhy-An-IEG-evaluation-of-World-Bank-support. 